\title{
Effect of Board Size, Board Composition and Board Meetings on Financial Performance of Listed Consumer Goods in Nigeria
}

\author{
EL-Maude, Jibreel Gambo ${ }^{1}$, Bawa, Ahmed Bello ${ }^{1}$, Shamaki Aranpu Rimamshung ${ }^{2}$ \\ ${ }^{1} \mathrm{PhD}$., Department of Accountancy, MAUTECH Yola, Nigeria \\ ${ }^{2}$ Nigeria Civil Service Union, National Headquarters, Abuja, Nigeria \\ Correspondence: EL-Maude, Jibreel Gambo, PhD., Department of Accountancy, MAUTECH Yola, Nigeria.
}

Received: February 20, 2018

Accepted: March 12, 2018

Online Published: May 9, 2018

doi:10.5539/ibr.v11n6p1

URL: https://doi.org/10.5539/ibr.v11n6p1

\begin{abstract}
The central thrust of this study is to examine the effect of board size, board composition and board Meetings on the financial performance of listed consumer goods in Nigeria over the period of ten years from 2006 to 2015. The study uses expo factor research design and purposive sampling technique (filter) as research design and sampling technique. The population of the study is twenty (20) listed consumer goods companies in Nigeria and a sample size of ten (10) companies were studied. The data was analysed by means of descriptive statistics, Correlation and Regression analysis using STATA (version 11). The descriptive result reveals that return on assets has minimum and maximum values of -0.0400 and 0.4700 respectively and the mean and standard deviation of 0.1199 and 0.1038 respectively. The study made use of secondary data generated from annual report and account of the sampled companies through Nigeria Stock Exchange fact book. The findings include the following: Board size is negatively significant at $1 \%$ with T. Value of _2.70, Board composition is positively significant at $1 \%$ with T- Value of 2.15 and finally, Board meeting is negatively insignificant with T- Value of _1.45. This study concluded that smaller board size are more effective than larger board size, good proportion of board composition is a good factor to enhance ROA of listed consumer goods companies in Nigeria and frequent board meeting will have negative effect on the ROA of listed consumer goods companies in Nigeria because it will limits the chances for external directors to conduct a meaningful oversight over management. Hence the study recommends among others; That smaller board size should be used in listed consumer goods companies in Nigeria to enhance their ROA, the listed consumer goods companies should continue to maintain good proportion of independence directors. The listed consumer goods companies in Nigeria should discourage unnecessary board meetings to allow board of directors perform other oversight function on the management so as to enhance the ROA of listed consumer goods companies in Nigeria.
\end{abstract}

Keywords: board size, board composition, board meetings, ROA, consumer goods

\section{Introduction}

Board structure of an organisation is the organisation's core layer which is critical to the corporate survival and or otherwise of an organization. It is often referred to as board of directors - a body of elected and or appointed members who have the mandate of jointly overseeing the attainment of the predetermine goal(s) of a company via the establishment of suitable policies and programmes which are effective and efficient. The legal responsibilities of boards and board members vary with the nature of the organisation and with the jurisdiction within which it operates (Mousa \& Al-manaseer, 2012). This by implication means the size and the composition of the board plays a pivotal role towards the achievement of the mandate of the board. Board size of an organisation is about the number of directors both the executive and the non executive. On the other hand, board composition is the proportion of non executive directors (independence) to total number of directors in an organisation (Adekunle \& Aghedo, 2014).

Return on assets (ROA) as the researcher's proxy is determined by taking net income and dividing it by total assets. The metric is used to understand how effectively a company is using their assets to generate earnings. Managers are directly responsible for the operations of the business and therefore the utilization of the firms' assets. Thus ROA allows users to assess how well a firms' corporate governance system is with particular reference to board characteristics in securing and motivating efficient management of the firm. 
In the past so many corporate organisations have been caught on getting involved in unethical practices for instance the discovery of financial scam by the Central Bank of Nigeria (CBN) after the consolidation exercise involving seven top bank executives in Nigeria which put the credibility of their corporate image under doubt which further deteriorates investors' confidence (Sanusi, 2012). It is against this background that the researcher considers the subject matter effect of board characteristics on the financial performance of listed companies in consumer goods industry as an issue worthy of study.

\section{Literature Review}

\subsection{Conceptual Review}

\section{Board Size}

Board size of an organisation is the number of directors on board of the organisation which includes executive and non-executive directors. Board size has highlighted in chapter one of this study influences the performance of an organisation. Lipton and Lorseh (1992) viewed it that small board size can improve the performance of an organisation because the benefits by larger boards of increased monitoring are outweighed by the poorer communication and decision making of larger groups and suggested an optimal board size between seven and nine directors. Mak and Kusnadi (2005) reported that small size boards are positively related to high firm value. In a Nigeria study, Sanda, Mikalu \& Garba (2010) reported that value is positively correlated with small, as opposed to large boards. The argument is that large boards are less effective and are easier for a CEO to be control. The cost of coordination and processing problems is also high in large boards and this makes decision taking difficult. On the other hand, smaller boards reduce the possibility of free-riding and therefore have the tendency of enhancing value of the firm. They measured the size of the board by the number of directors serving on such boards and expect this to have a negative relationship with the value of the firm.

\section{Board Composition}

Section 359 (4) of Companies and Allied Matter Acts (2004) provides for board composition to be on equal proportion. The new Security and Exchange Commission (SEC) guideline was silent on the number. However the best international practice is having a board with more non-executive than executive directors for ensuring independence of the board. Board composition normally concerns issues related to board independence (including independence of board committees) and diversity (firm and industry experience, functional backgrounds, etc.) of board members. Board independence refers to a corporate board that has a majority of independent outside directors. Compared to an insider-dominated board, an outsider-dominated board is believed to be more vigilant in monitoring managerial behaviours and decision-making of the firm. A board that consists of directors with a diverse set of functional expertise (marketing, engineering, finance, etc.) industry experiences, educational qualifications, ethnic and gender mix might be better equipped to deal with a wide range of issues facing the firm and provide executives with advice and consultation from multiple perspectives.

\subsection{Return on Assets (ROA)}

An indicator of how profitable a company is relative to its total assets. ROA gives an idea as to how efficient management is at using its assets to generate earnings. Calculated by dividing a company's annual earnings by its total assets, ROA is displayed as a percentage. Sometimes this is referred to as "return on investment". Return on assets (ROA) is also a measure of performance widely used in the governance literature for accounting-based measures (Finkelstein \& D'Aveni 1994; Kiel \& Nicholson 2003; Weir \& Laing 2001). It is a measure which assesses the efficiency of assets employed (Bonn, Yoshikawa \& Phan 2004) and shows investors the earnings the firm has generated from its investment in capital assets. Efficient use of a firm's assets is best reflected by its rate of return on its assets. ROA is an indicator of short-term performance which is calculated as net income divided by total assets (Finkelstein \& D'Aveni 1994). Since managers are responsible for the operation of the business and utilization of the firm's assets, ROA is a measure that allows users to assess how well a firm's corporate governance system is working in securing and motivating efficiency of the firm's management (Epps \& Cereola, 2008).

\subsection{Board Size and Financial Performance}

Studies on board size and firm performance have generated conflicting results, for example (Yermack, 1996; Kiel \& Nicolson, 2003; Guest, 2009; Adams \& Mehran, 2012; Wintoki, Linck \& Netter, 2012). Moreover, Yermack (1996) was one of the first researcher that investigated board size and firm performance. Using a sample 452 large US firms between 1984 and 1991, found a negative relationship between board size and firm performance measured by Tobin's Q. This finding is robust with specific characteristics of a firm such as firm size, growth opportunities, board structure, director ownership and industry sector. 
In particular, he indicates that corporate performance declines steadily if the board size is between four and ten directors. Beyond this limit, there is no impact between board size and corporate performance. Nigerian studies (Ujunwa, 2012; Adebayo et al., 2013; Dabor, Isiavive, Ajagbe \& Oke., 2015) and non-Nigerian studies (Guest, 2009; O'Connell \& Cramer, 2010; Guo \& Kga, 2012) have mostly found consistent results with those of Yermack (1996) that board size is negatively related to firm performance. Using a sample of 30 listed firms in Nigeria, Adebayo et al., (2013), measured by ROE and EPS found a significant negative relationship between board size and organizational performance.

In contrast, other Nigerian studies (Kajola, 2008; Sanda et al., 2010; Akpan \& Amran, 2014; Ironkwe \& Adee, 2014; Ilaboya \& Obaretin, 2015) and non-Nigerian studies (Adams \& Mehran, 2012; Owusu, 2012) have found a positive relationship between board size and firm performance. Using a sample of 20 Nigerian listed firms from 2000 to 2006 measured by ROE, Kajola (2008) found a positive and statistically significant relationship. Also, Ironkwe and Adee (2014) found a positive and statistically significant relationship between board size and firm performance, in sample of 40 financial firms in Nigeria. Using Time series data from 166 firms quoted on the Nigerian Stock Exchange market from 2005 to 2012 in the Food and Beverages sector, Ilaboya and Obaretin (2015) found a similar result which showed a positive relationship between board size and corporate financial performance measured by PAT. The study reports a mean board size of 9 which is consistent with (Jensen, 1993).

\subsection{Board Composition and Financial Performance}

Evidence on the relationship between the proportion of non-executive directors on the board and firm performance is mixed (Connelly \& Limpaphayom, 2004); (Shakir, 2004); (Haniffa \& Hudaib, 2006); (Ghosh, 2006); (Jacking \& Johl, 2009); (Rashid et al., 2010); (Uwuigbe, 2011); (Al-Matari, 2013); (Ogbulu \& Emeni, 2012); (Satirenjit \& Oladipupo, 2014); (Adekunle \& Aghedo, 2014). They are mixed in the sense that some of the study reviewed show positive relationship between board characteristics and financial performance while some shows negative relationship between the variables.

Prior Nigerian studies (Olayinka, 2010); ( Ironkwe \& Adee, 2014); (Shehu \& Musa, 2014) and Non-Nigerian studies (El Mehdi, 2007); (Jacking \& Johl, 2009); (Al-Matari, 2013) have reported a positive relationship between board composition and firm performance. In particular, El Mehdi (2007) in a sample of 24 listed companies in Tunisia from 2000 - 2005 found that the proportion of outside directors is positively associated with firm performance measured by Marginal Q. Similarly, Al-Matari (2013) also found that the proportion of non-executive directors is positively related to ROA. In Nigeria, some studies also support these empirical evidences. For example Olayinka (2010) found a positive relationship between board composition and corporate financial performance (ROE and ROCE) in sample of 30 companies for year 2007. Also, using a sample 13 listed deposit money banks for the period 2007 to 2011, Shehu and Musa (2014) found that board composition positively, strongly and significantly influence firm performance measured by ROA. These similar findings suggest that boards with higher proportion of outside directors offer higher performance.

In contrast, other Nigerian Studies (Uwuigbe, 2011; Ogbulu \& Emeni, 2012; Garba \& Abubakar, 2014) and non-Nigerian study (Guest, 2009) have reported that the proportion of independent non-executive directors representation on the board is negatively related to firm performance. Using a sample of 157 Zimbabwean listed firms from 2000 to 2005, Mangena et al.(2012) found that the proportion non-executive directors is significant and negatively related to firm performance measured by Tobin's Q. Similarly, Mahrous (2014) reported a statistically negative relationship between non-executive board members and ROE, in a sample of 50 Egyptian listed non-financial companies from 2006 - 2010. This evidence is also the same with those found in Nigeria. For instance Ogbulu and Emeni (2012) found a negative association between board composition and firm performance in a sample of 14 Nigerian listed banks as at December 2008. Also, Garba and Abubakar (2014), using 12 listed insurance companies for the period 2004 to 2009 found a negative and significant relationship between board composition and firm performance measured by Tobin's Q and ROE. This indicates that the benefit of board independence, objectivity and experience expected from the representation of outside directors to influence board strategic decisions appears to hold back managerial initiative through too much monitoring.

A third group of studies suggest that board composition has no effect on firm performance (Ghosh, 2006; Rashid et al., 2010). For example, Ghosh (2006) found out that the proportion of outside directors has no significant impact on firm performance measured by ROA and adjusted Tobin's Q in 127 Indian listed manufacturing firms. Similarly, Using a sample of 274 Bangladeshi firm-years from 2005 - 2009, Rashid et al. (2010) found that outside (independent) directors cannot add value to the firm's economic performance measured by ROA and Tobin's Q in Bangladesh. 
In Nigeria where this study is based, evidence has also shown that board composition has no relationship with firm performance (Kajola, 2008; Sanda et al., 2010; Paul, Friday \& Godwin, 2011; Mansur \& Ahmad, 2013). Using a sample of 20 listed firms, Kajola (2008) found no relationship between board composition and firm performance measured by ROE and Profit Margin (PM) from 2000 - 2006. Also, Sanda et al. (2010) reported that larger proportion of outside directors has no impact on firm performance measured by ROA, ROE, Tobin's $\mathrm{Q}$ and P/E ratio from $1996-1999$.

\subsection{Summary}

From the above mentioned, one can maintain that the effect of board characteristics on the financial performance of firms cannot be ignored because the increase in the financial performance is necessary for any firm in order to survive in the long run. Because Board of directors play a crucial role in the company and their characteristics affect how corporate governance standards are applied and enacted. Therefore, it is important to test the effect of board characteristics on firm financial performance.

In summary, previous studies regarding the relationship between board characteristics and firm's performance across Nigeria has been conducted in the various sectors of the Nigerian economy (e.g. Ilaboya \& Obaretin (2015) in the consumer goods sector between 2005 and 2012; Shehu \& Musa (2014) in the banking sector between 2007 and 2011; Garba \& Abubakar (2014) in the insurance sector between 2004 and 2009). However, there are none of these studies empirically examine the board characteristics in the consumer goods in Nigeria to year 2015. Empirically, this study aims to fill the gap by focusing on the listed consumer goods companies in Nigeria during the period of 2006-2015 (10years) by analyzing whether different board characteristics of different firms have an effect on the return on assets of these companies.

Also, review of different perspectives clarifies that there is need to take an integrated approach rather than a single perspective to understand the effect of corporate governance on firm performance. While agency theory places primary emphasis on shareholders' interests, stakeholder theory places emphasis on taking care of interests of all stakeholders, and not just the shareholders. In line with this, Jensen (2001) suggests enlightened value maximisation, which utilises much of enlightened stakeholder theory but accepts maximisation of the long-run value of the firm as the criterion for making the requisite trade-offs among stakeholders and therefore solves the problems that arise from multiple objectives that accompany traditional stakeholder theory. Also, stewardship theory suggests that due to their information and knowledge advantages, better financial performance is likely to be associated with greater managerial trust and powers. Finally, resource dependence theory indicates that internal corporate governance structures like the board of directors help to link the firm to critical business inputs needed for higher financial performance.

Having reviewed the above theory the researchers adopted agency theory as the underpinning theory for this study as it aided the study as far as principal agent relationship is concern, supported by stakeholder theory which take into consideration all stakeholders in the business such as investors, creditors, suppliers and employees and resource dependence theory, the company uses the experience and connections of the board of directors to raise fund for the business from outside and within the environment. This is in line with Stiles (2001) who calls for multiple theoretical perspectives and Roberts et al (2005) who suggests theoretical pluralism. The gap here is that despite the call for multiple theoretical perspective most prior studies on board characteristics and firm performance used only agency theory. In this study we adopted agency theory as the underpinning theory for this study supported by stakeholder theory and resource dependence theory.

\section{Methodology}

This study uses ex-post facto research design; this is because it is quantitative research based on a positivist paradigm and used deductive reasoning. The study adopted a positivist approach, because a positivist approach seeks facts or causes of social phenomena. The reasoning is deductive because the hypotheses were derived first and the data were collected later to confirm or negate the propositions. This study covered a period of 10 years i.e. from 2006 to 2015 (10 years). Data was elicited from annual financial reports and accounts of the selected listed consumer goods companies in Nigeria. The population for this study consists of all the 20 listed consumer goods companies in Nigeria as at $31^{\text {st }}$ December, 2015 out of which only 10 companies who had $31^{\text {st }}$ December as their financial year were selected. In analysing the data collected, regression analysis was used using STATA 11.0

\section{Model Specification}

In order to test the hypotheses developed in the first chapter of this study, the following regression model was used: 
$\operatorname{ROA~i}_{\mathrm{t}}=\beta 0+{ }_{\beta 1 \mathrm{BSIZEit}}+\beta 2 \mathrm{BCOMP}_{\mathrm{it}}+\beta 3 \mathrm{FS}_{\mathrm{it}}+\mu_{\mathrm{it}}(1)$

Where:

BSIZE: Board Size; BCOMP: Board Composition; FS: Firm Size; $\mu$ : Error Term

\section{Data Presentation, Analysis and Interprentation}

\subsection{Descriptive Statistics}

Table 4.1. Descriptive statistics

\begin{tabular}{llllllll}
\hline Variable & Minimum & Maximum & Mean & Std. Dev. & Skewness & Kurtosis & Obs \\
\hline ROA & -0.0400 & 0.4700 & 0.1199 & 0.1038 & 0.7961 & 3.7525 & 100 \\
FS & 10.1365 & 26.2557 & 21.5167 & 3.6418 & -1.2361 & 4.5868 & 100 \\
BSIZE & 7.0000 & 16.0000 & 9.9800 & 2.2247 & .8164 & 2.3576 & 100 \\
Bcomp & 0.7000 & 0.9000 & 0.5805 & 0.2348 & -.6759 & 2.3960 & 100 \\
BM & 4.0000 & 0.9000 & 5.2800 & 1.3639 & 1.0688 & 3.6727 & 100 \\
\hline
\end{tabular}

Source: Researcher's Analysis (2016) using STATA version 11

Table 4.1 presents the descriptive analysis of the study. The descriptive result reveals that return on assets has minimum and maximum values of -0.0400 and 0.4700 respectively and the mean and standard deviation of 0.1199 and 0.1038 respectively. Meaning within the study period the performance is low since it recorded a minimum value and a relatively higher standard deviation. The table also shows that the minimum and maximum values of firm size are 10.1365 and 26.2557 respectively and has a mean and standard deviation of 21.5167 and 3.6418 respectively which demonstrate a better performance since the standard deviation is relatively low.

Similarly, board size has a minimum of 7.0000 and a maximum of 16.0000 with an average of 9.9800 and standard deviation of 2.2247. The size of the board varies widely across the sample companies and the minimum is 7 and the maximum is 16 . The important factor that explains the large disparity of the size could be as a result of wide difference of the sample companies' size as represented by their total assets. Larger firms tend to have more directors on their board, which is a reflection of the company's vast equity shareholding structure.

Finally, the skewness and kurtosis statistics revealed that the data obtained for the variables including dependent and independent variables are normally distributed. Therefore, the study is considered valid which substantiates the validity of the regression result.

\subsection{Correlation Matrix}

In order to establish the nature of relationship between dependent and independent variables and to determine whether multicolinearity exists among the variables of the study, the Pearson correlation analysis was used.

Table 4.2. Correlation Matrix

\begin{tabular}{llllll}
\hline VAR & ROA & F size & B size & Bcomp & Bm \\
\hline ROA & 1.0000 & 1.0000 & & \\
Fsize & 0.0623 & 0.4264 & 1.0000 & & \\
Bsize & -0.2095 & 0.4630 & 0.2429 & 1.0000 & 1.0000 \\
Bcomp & 0.1093 & 0.1765 & -0.1346 & 0.1955 & \\
Bm & 0.0476 & & & \\
\hline
\end{tabular}

Source: Researchers' Analysis (2016) using STATA version 11

$=$ Significant at $1 \%(0.01)=$ significant at $5 \%(0.05)=$ Significant at $10 \%(0.10)$.

Table 4.2 shows the correlation between the variables. The table shows a positive significant relationship between ROA and Fsize from the co-efficient of 0.0623 which is significant at $1 \%$. This implies that as the Fsize increase the firm performance (ROA) will also increases.

Bsize has a significant negative relationship with ROA as shown by coefficient of -0.2095 which is significant at $1 \%$. This implies that larger board size will lead to lower return on Assets of consumer goods companies listed in Nigeria. Bcomp shows a significant positive relationship with ROA based on the correlation matrix result that has a coefficient of 0.1093 which is significant at $10 \%$. This means that more independent directors on board will enhance firm performance. 
However, the relationship between the variables themselves is not found to be significant to the extent that one can conclude that there is multicollinearity unless the variance inflation factor and tolerance values are comparatively beyond the established rule of thumb. Thus, the variance inflation factor (VIF) and tolerance value are advanced measures for assessing multicollinearity among the regressors. The variance inflation factor (VIF) and the tolerance values were determined with the use of STATA and were found to be concurrently less than ten and one respectively.

4.3 Regression Analysis (OLS)

Table 4.3. Regression Result

\begin{tabular}{lllll}
\hline Variables & Coefficients & T-statistics & T-significant & VIF/Tolerance \\
\hline Constant & .5001 & 3.61 & 0.000 & \\
Fsize & & 1.24 & 0.218 & $1.45 / 0.688$ \\
Bsize & 0.0041 & -2.70 & 0.006 & $1.28 / 0.780$ \\
& & & 0.034 & $1.14 / 0.876$ \\
Bcomp & -0.1490 & 2.15 & 0.1500 & $1.11 / 0.899$ \\
Bm & 0.0364 & -1.45 & & 0.1320 \\
$\mathrm{R}^{2}$ & -.0634 & & & 3.61 \\
Wald Chi & & & & 0.0087 \\
Wald - sig & & & &
\end{tabular}

Source: Researchers' Analysis (2016) using STATA version 11

The result from table 4:3 shows that Bsize has a coefficient value of -0.1490 and T-statistics value of -2.70 while T-sig as 0.006 which is not significant at any level. The negative value of the coefficient -0.1490 signifies that Bsize and ROA are negatively related which implies that for every $1 \%$ increase in Bsize of consumer goods companies will lead to decrease in the ROA by $1.5 \%$. This provides an evidence for accepting the Null Hypothesis one which states that Bsize has no significant impact on performance of listed consumer goods companies in Nigeria. This finding is in line with Yermack (1996) he was one of the first researcher that investigated board size and firm performance. Using a sample 452 large US firms between 1984 and 1991, found a negative relationship between board size and firm performance measured by Tobin's Q. The finding is robust with specific characteristics of a firm such as firm size, growth opportunities, board structure, director ownership and industry sector. In particular, Yermack indicates that corporate performance declines steadily if the board size is between four and ten directors. Beyond this limit, there is no impact between board size and corporate performance. The findings is also consistent with the (Ujunwa, 2012; Adebayo et al., 2013; Dabor, Isiavive, Ajagbe \& Oke., 2015).

Table 4.3 also revealed that Bcomp has a coefficient value of 0.0364 , T-statistics of 2.15 and revealed a T-sig of 0.034 which is significant at $10 \%$ level of significance. From the coefficient value of 0.0364 one can say that there is a positive relationship between Bcomp and ROA of consumer goods companies listed in Nigeria .This signifies that when Bcomp increase by $1 \%$ return on assets will increase by $3.6 \%$. The result shows that the Null Hypothesis two that state that bcomp does not has significant impact on ROA does not hold water and must be rejected. This findings is in line with the findings of El mehdi (2007), Al-matari (2013) and Olayinka (2010).That means board with higher proportion of outside directors offer higher performance.

Finally, on the contrary, Bm shows a coefficient of -0.634 ,T-statistics of -1.45 and T-sig 0.15 which is not significant at all level of significance. The negative coefficient signifies that board meeting and firm performance of listed consumer goods companies in Nigeria are inversely related meaning that whenever Bm increase by $1 \%$ the firm performance will decrease by $63 \%$. The result provide an evidence to accept the Null Hypothesis that state Bm has no significant impact on ROA of consumer goods companies listed in Nigeria. This finding is consistent with Jensen (1993) opines that: "daily tasks those continue most of the board's meeting time and hence this limits the chances for external directors to conduct a meaningful oversight over management". Jensen further stressed that board should not be over active as activity of board represents a reaction to adverse performance. It is also consistent to some empirical studies that found a negative impact of board meeting on the financial performance such as Danoshana and Ravivathani (2014), Garcia-Sanchez (2010), and Kamardin (2009).

The cumulative $\mathrm{R}^{2}(0.1320)$ which is the multiple coefficient of the determination gives the proportion of the total variation in the dependent variable explained by the independent variables jointly. Hence, it signifies that $13 \%$ 
of the total variation in ROA of consumer goods companies listed in Nigeria is caused by board size, board composition and board meeting. This indicates that the model is fit and the regressors are properly selected, combined and used. This further implies that for any changes in the attributes of listed consumer goods companies in Nigeria, their ROA will be directly affected.

The F-statistics or Wald chi-squared statistics are really the same thing in that, after normalization chi-squared is the limiting distribution of the $\mathrm{F}$ as the denominator degrees of freedom goes to infinity. Therefore, the Wald chi square of 3.61 which is significant at $1 \%$ indicates that the corporate attributes and ROA model is fit.

\section{Conclusion and Recommendations}

The study concludes that smaller board size are more effective than larger board size because smaller good board size with upright personal traits relevant core competences and entrepreneurial spirit knowledgeable in board matters will enhance ROA listed consumer goods companies in Nigeria. Therefore larger board size should be discouraged. Similarly, the study concludes that board composition is an important factor that can enhance Return on Assets of listed consumer goods companies in Nigeria. Therefore, number of independent (non-executive) directors on the Board is an important monitoring and control device. The non- executive directors have the ability to monitor and control the extremes of the executive directors, thereby protecting the interest of the share holders and other stake holders. They are also free from managerial influence and capable of monitoring them effectively which will enhance the Return on Assets of listed consumer goods companies in Nigeria. Finally, frequent board meeting will have negative effect on the ROA of listed consumer goods companies in Nigeria because it will limits the chances for external directors to conduct a meaningful oversight over management.

\section{References}

Adams, R. B., \& Mehan, H. (2012). Bank board structure and performance: Evidence for large bank holding companies. Journal of Financial Intermediation, 21, 243-267. https://doi.org/10.1016/j.jfi.2011.09.002

Adams, R., \& Mehran, H. (2003). Is corporate governance different for Bank holding companies? Economic Policy Review - Federal Reserve Bank of New York, 9(1), 123-142. https://doi.org/10.2139/ssrn.387561

Adebayo, O. S., Ayeni, G. O., \& Oyewole F. A. (2013).Relationship between Corporate Governance and Organizational Performance: Nigerian Listed Organizations Experience. International Journal of Business and Management Invention, 2(9), 1-6.

Adekunle, S. A., \& Aghedo, E. M. (2014). Corporate governance and financial performance of selected quoted companies in Nigeria. European Journal of Business and Management, 6(9). Retrieved $1^{\text {st }}$ April, 2016 from www.iiste.org/Journals/index.php/EJBM/article/viewFile/11758/12113

Akpan, E. O. (2014). Corporate Board Meetings and Company Performance: Empirical Evidence from Nigerian Quoted Companies. Global Journal of Commerce \& Management Perspective, 4(1), 75-82. Retrieved from gifre.org/library/upload/volume/75-82-CORPORATE-vol-4-1-gjcmp.pdf

Akpan, E. O., \& Amran, N. A. (2014). Board characteristics and company performance: Evidence from Nigeria. Journal of Finance and Accounting, 2(3), 81-89. https://doi.org/10.11648/j.jfa.20140203.17

Al-Matari E. M., Al-Swidi, A. K., \& BtFadzil, F. H. (2014). The Effect on the relationship between board of directors characteristics on firm performance in Oman: Empirical study. Middle-East Journal of Scientific Research, 21(3), 556-574.

Al-Matari, E, M., Bt Fadzil, F. H. \& Al-Swidi, A. K. (2014).The Moderating Effect of Board Diversity on the Relationship between Board of Directors Characteristics and Firm Performance in Oman: Empirical Study. Middle-East Journal of Scientific Research, 21(5), 782-791.

Bonn, I., Yoshikawa, T., \& Phan, P. H. (2004), 'Effects of Board Structure on Firm Performance: A Comparison between Japan and Australia', Asian Business \& Management, 3, 105-125. https://doi.org/10.1057/palgrave.abm.9200068

Cadbury, A. (1992). Report of the committee on the financial aspects of corporate governance (Cadbury Report). London: Gee. Retrieved 25th May, 2016 from European Corporate Governance Institute website: www.ecgi.org/codes/documents/cadbury.pdf

Connelly, J. T., \& Limpaphayom, P. (2004). Environmental reporting and firm performance:

Dabor, A. O., Isiavwe, D. T., Ajagbe, M. A., \& Oke, A. O. (2015). Impact of corporate governance on firms' performance. International Journal of Economics, Commerce and Management, III(6), 634-653. 
Danoshana, S., \& Ravivathani, T. (2014). Impact of corporate governance framework on the organizational performance. A study on financial institutions in Sri Lanka. International Journal of Technological Exploration and Learning, 16(1), 73-78

El Mehdi, K. I. (2007). Empirical Evidence on Corporate Governance and Corporate Performance in Tunisia, Corporate governance: An international review, 15(6), 1429-1441. https://doi.org/10.1111/j.1467-8683.2007.00655.x

Elsayed, K., (2007). Does CEO duality really affect corporate performance? Corporate Governance: an international review, 15(6), 1203-1214. https://doi.org/10.1111/j.1467-8683.2007.00641.x

Eng, L. L., \& Mak, Y. T. (2003) Corporate governance and voluntary disclosure: Journal of Accounting and Public Policy, 22(4), 325-345. https://doi.org/10.1016/S0278-4254(03)00037-1

Epps, R. W., \& Cereola, S. J. (2008). Do institutional shareholders services (IIS) Corporate governance rating reflect a company's operating performance. Critical Perspective on Accounting, 19, 1135-1148. https://doi.org/10.1016/j.cpa.2007.06.007

Finkelstein, S., \& D'Aveni, R. A. (1994). CEO duality as a double-edged sword: How boards of directors balance entrenchment avoidance and unity of command. The Academy of Management Journal, 37(5), 1079-1108. https://doi.org/10.2307/256667

Garba, T., \& Abubakar, B. A. (2014). Corporate board diversity and financial performance of Insurance companies in Nigeria: An application of panel data approach. Asian Economic and Financial Review, 4(2), 257-277

Garcia-Sanchez, I. M. (2010). The effectiveness of corporate governance: Board structure and business technical efficiency in Spain. CEJOR, 18, 311-339. https://doi.org/10.1007/s10100-009-0112-4

Ghosh, S. (2006). Do board characteristics affect corporate performance? Firm-level evidence for India . Applied Economics Letters, 13, 435-443. https://doi.org/10.1080/13504850500398617

Gillan S. (2006).Recent Developments in Corporate Governance: An overview, Journal of Corporate Finance, 12, 381-402. https://doi.org/10.1016/j.jcorpfin.2005.11.002

Guest, P. M. (2009). The impact of board size on firm performance: Evidence from the UK. The European Journal of Finance, 15(4), 385-404. https://doi.org/10.1080/13518470802466121

Guo, Z., \& Kga, U. K. (2012). Corporate governance and firm performance of listed firms in Sri Lanka. Procedia-Social and Behavioral Sciences, 40, 664-667. https://doi.org/10.1016/j.sbspro.2012.03.246

Habbash, M. (2010). The Effectiveness of Corporate Governance and External Audit on Constraining Earnings Management Practice in the UK(Doctoral dissertation).

Haniffa, R. M., \& Cooke, T. E. (2002).Culture, corporate governance and disclosure in Malaysian corporations. Abacus, 38(3), 317-349. https://doi.org/10.1111/1467-6281.00112

Haniffa, R., \& Hudaib, M. (2006). Corporate governance structure and performance of Malaysian listed companies. Journal of Business Finance \& Accounting, 33(7-8), 1034-1062. https://doi.org/10.1111/j.1468-5957.2006.00594.x

Heenetigala, K. (2011). Corporate Governance Practices and Firm Performance of Listed Companies in Sri Lanka (Doctoral dissertation).

Ilaboya, O. J., \& Obaretin O. (2015). Board characteristics and firm performance: Evidence from Nigerian quoted companies. Academic Journal of Interdisciplinary Studies, 4(1), 283. https://doi.org/10.5901/mjss.2015.v4n1p283

Ironkwe, U., \& Adee, G. M. (2014). Corporate governance and financial firms performance in Nigeria. Journal of Exclusive Management Science, 3(8), 1-6.

Jackling, B., \& Johl, S. (2009). Board Structure and Firm Performance: Evidence from India's Top Companies. $\begin{array}{llll}\text { Corporate } \quad \text { Governance: } \quad \text { An } & \text { International }\end{array}$ https://doi.org/10.1111/j.1467-8683.2009.00760.x

Jensen, M. (1993). "The Modern Industrial Revolution: Exit and the Failure of Internal Control Systems". Journal of Finance, 48(3), 831-880. https://doi.org/10.1111/j.1540-6261.1993.tb04022.x

Kajola, S. O. (2008). Corporate governance and firm performance: The case of Nigerian listed firms. European Journal of Economics, Finance and Administrative Sciences, 14, 16-28. 
Kamardin, H. (2009). The impact of corporate governance and board performance on the performance of public listed companies in Malaysia. Ph.D. Dissertation, University Sains Malaysia.

Kiel, G. C., \& Nicholson, G. J. (2003). Board composition and corporate performance: How the Australian experience informs contrasting theories of corporate governance. Corporate Governance: An International Review, 11(3), 189-205. https://doi.org/10.1111/1467-8683.00318

Lipton, M., \& Lorseh, J. W. (1992). A modest proposal for improved corporate governance. Business Lawyer, 48, 59-77.

Mahrous, S. A. (2014). The Effect of Board Characteristics on the Financial Performance of Firms: An Empirical Study on the Most Active Firms in the Egyptian Stock Exchange (Master's Thesis). Retrieved 26 ${ }^{\text {th }}$ March, 2016 from www.aast.edu/pheed/.../pdf_retreive.php?url=50415...pdf...staffpdf

Mak, Y. T., \& Kusnadi, Y. (2005) Size really matters: Further evidence on the negative relationship between board size and firm value, June 2005, 13(3), 301-318.

Mangena, M., Tauringana, V., \& Chamisa, E. (2012). Corporate boards, ownership structure and firm performance in an environment of severe political and economic crisis. British Journal of Management, 23, 23-41. https://doi.org/10.1111/j.1467-8551.2011.00804.x

Mansur, L. K., \& Ahmad B. A. (2013).Board Composition, Executive duality and Performance of Banks in the Post-Consolidation Era in Nigeria. International Journal of Academic Research in Economics and Management Sciences, 2(1), 109-122. Retrieved from www.hrmars.com/admin/pics/1500.pdf

Mousa, F., \& Al Manaseer (2012). The impact of corporate governance on the performance of Jordanian Banks.

Muhammad A.I., \& Muhammed, S. (2015). The Impact of Board Characteristics on Corporate Social Responsibility Disclosure: Evidence from Nigeria Food Product. International Journal of management science and business Administration Volume 1.

O'Connell, V., \& Cramer, N. (2010). The relationship between firm performance and board characteristics in Ireland. Journal of European Management, 28, 387-399. https://doi.org/10.1016/j.emj.2009.11.002

Ogbechie, C. I. (2012). Key Determinants of Effective Boards of Directors - Evidence from Nigeria (Doctoral dissertation).

Ogbulu, O. M., \& Emeni, F. K. (2012). Corporate Governance and Bank Performance in Nigeria: A Correlation Analysis. Economics and Finance Review, 2(4), 14-23.

Olayinka, M. U. (2010). The impact of board structure on corporate financial performance in Nigeria. International Journal of Business and Management, 5(10), 155-166.

Owusu, A. (2012). An empirical investigation of the relationship between corporate governance and firm performance: Evidence from Ghana. (Doctoral dissertation).

Paul, A., Friday, O., \& Godwin, O. (2011). Board composition and corporate performance: An analysis of evidence from Nigeria. Research Journal of Finance and Accounting, 2(4), 64-73.

Rashid, A., De Zoysa, A., Lodh, S., \& Rudkin, K. (2010). Board Composition and Firm Performance: Evidence from Bangladesh. Australasian Accounting, Business and Finance Journal, 4(1), 76-95.

Roberts, J., McNulty, T. \& Stiles, P. (2005). 'Beyond Agency Conceptions of the Work of the Non-Executive Director: Creating Accountability in the Boardroom'. British Journal of Management, 16, 1-22. https://doi.org/10.1111/j.1467-8551.2005.00444.x

Sanda, A. U., Mikailu, A. S., \& Garba, T. (2010).Corporate governance mechanisms and firms' financial performance in Nigeria. Afro-Asian Journal of Finance and Accounting, 2(1), 22-39. https://doi.org/10.1504/AAJFA.2010.035193

Sanusi, L. S. (2012). Banking reform and its impact on the Nigerian economy.

Satirenjit, K. J., \& Oladipupo, L. S. (2014). Impact of board composition on firm performance: A study on listed firms in Malaysia. Journal of Contemporary Management Sciences, 3(3), 94-102.

Shakir, R. (2004). Board size, board composition and property firm performance. Pacific Rim Property Research Journal, 14(1), 1-16.

Shehu, U. H., \& Musa A. F. (2014). Board of director's characteristics and performance of listed deposit money banks in Nigeria. Journal of Finance and Bank Management, 2(1), 89-105. 
Stiles, P. (2001). The Impact of the Board on Strategy: An Empirical Examination. Journal of Management Studies, 38(5), 627-650. https://doi.org/10.1111/1467-6486.00252

Ujunwa, A. (2012). Board characteristics and the financial performance of Nigerian quoted firms. Corporate Governance, 12(5), 656-674. https://doi.org/10.1108/14720701211275587

Uwuigbe, O. R. (2011). Corporate Governance and Financial Performance of Banks: A Study of Listed Banks in Nigeria (Doctoral dissertation).

Van Ees, H., Gabrielsson, J., \& Morton, H. (2009). Towards a behavioural theory of Boards and corporate governance. Corporate Governance: An International Review, 17(3), 307-319. https://doi.org/10.1111/j.1467-8683.2009.00741.x

Vefeas, N. (1999). Board meeting frequency and firm performance. Journal of Financial Economics, 53, 113-142. https://doi.org/10.1016/S0304-405X(99)00018-5

Weimer, J., \& Pape, J. C. (1999). A taxonomy of systems of corporate governance. corporate governance: An international Review, 7(2), 152-166. https://doi.org/10.1111/1467-8683.00143

Weir, C., \& Laing, D. (2001). The performance-governance relationship: The effects of Cadbury Compliance on UK Quoted Companies. Journal of Management and Governance, 4, 265-281. https://doi.org/10.1023/A:1009950903720

Wintoki, M. B., Linck, J. S., \& Netter, J. M. (2012). Endogeneity and the dynamics of internal corporate governance. Journal of Financial Economics, 105, 581-606. https://doi.org/10.1016/j.jfineco.2012.03.005

Yermack, D. (1996). Higher market valuation of companies with a small board of directors. Journal of Financial Economics, 40(2). https://doi.org/10.1016/0304-405X(95)00844-5

\section{Copyrights}

Copyright for this article is retained by the author(s), with first publication rights granted to the journal.

This is an open-access article distributed under the terms and conditions of the Creative Commons Attribution license (http://creativecommons.org/licenses/by/4.0/). 